
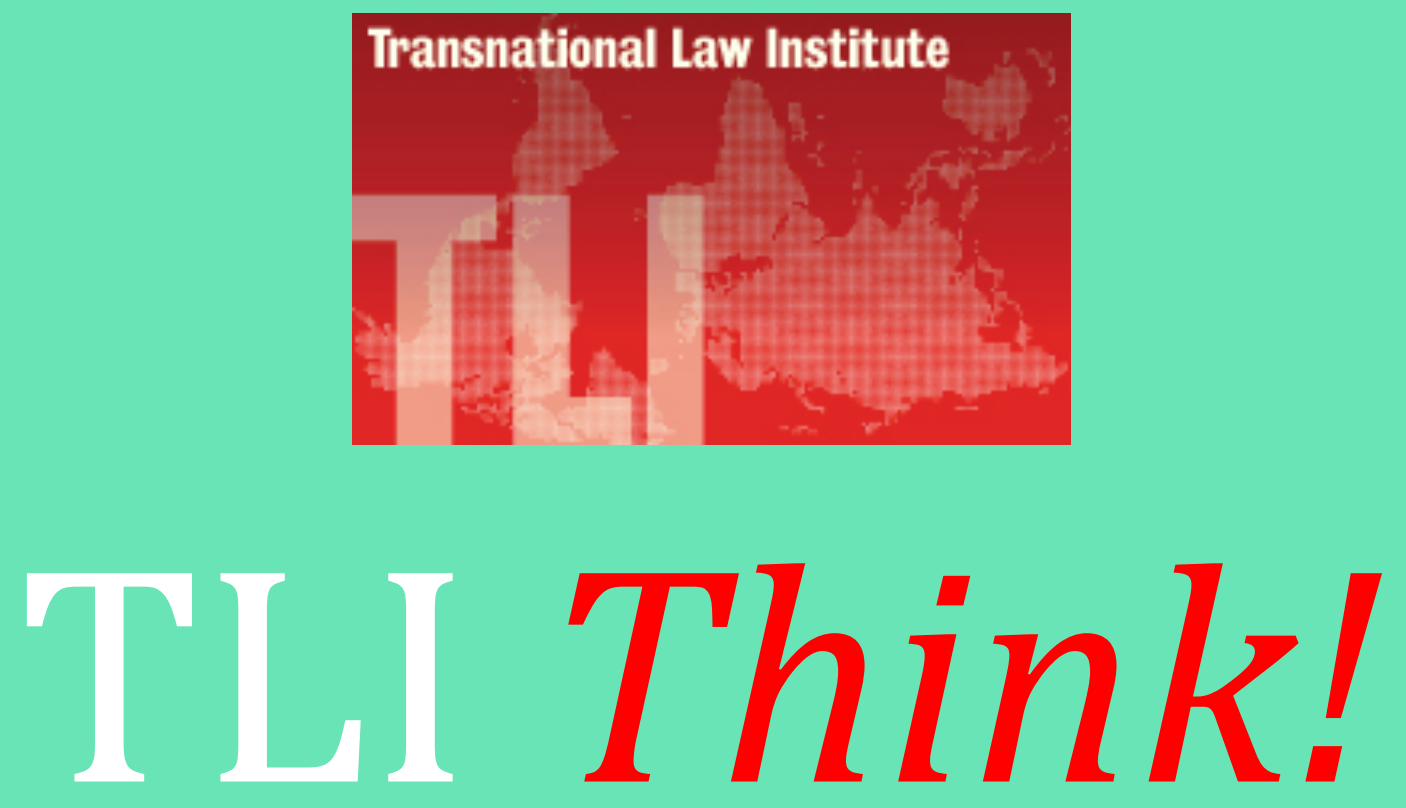

A Dickson Poon Transnational Law Institute, King's College London Research Paper Series

\title{
New 'Legal' Actors, Norms And Processes: Formal And Informal Indigenous Land Rights Norms In The Oyu Tolgoi Project, Mongolia
}

\author{
Kinnari Bhatt
}

\section{TLI Think! Paper 63/2017}

Editor: Peer Zumbansen, Director TLI / Managing Editor: Dayan Farias Picon

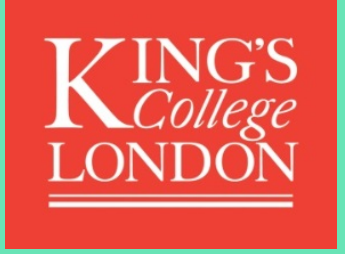

The Dickson Poon School of Law, King's College London

W: http://www.kcl.ac.uk/law/tli E: tli@kcl.ac.uk

This paper can be downloaded without charge at https://ssrn.com/abstract=2995505 
Abstract: This paper draws attention to the role of new actors, norms and processes in global governance. Specifically, it examines the Oyu Tolgoi copper and gold mine in Mongolia and the role played by weak domestic laws on land and indigenous rights as crucial for understanding the entry of new 'legal' actors, 'rights' and 'remedies' into the legal landscape on land and global governance. Drawing on the struggles of nomadic pastoralist resettled to make way for the mine, I expose the relevance of project finance structures, informal land policies, 'soft' grievance mechanisms connecting investors to communities and a nascent trend seeing financial institutions committed to the financing of the project factually determine issues of 'indigenous' identity and legal status. Through this case I hope to draw attention to a larger pattern of 'real world' developments connected to the changing role of the state, the related emergence of new actors, norms and processes in modern processes of globalisation and financialization, and the effect of the same on the rights of affected communities.

Keywords: 'Actors, norms, processes', Mongolia, indigenous land rights, financial investors, sovereignty.

\section{Institutional affiliation:}

\section{Kinnari Bhatt}

Transnational Law Institute, King's College London, The Dickson Poon School of Law Visiting Fellow

Somerset House East Wing

London, England WC2R 2LS

United Kingdom

Email: kinnari@bhattsolicitor.info 


\title{
New 'Legal' Actors, Norms And Processes: Formal And Informal Indigenous Land Rights Norms In The Oyu Tolgoi Project, Mongolia ${ }^{1}$
}

\author{
Kinnari Bhatt ${ }^{2}$
}

\section{The Oyu Tolgoi Project: Mapping New Actors, Norms and Processes}

The inability of formal Mongolian law to provide legal protection to pastoralist herders displaced from their traditional lands has, this paper will argue, led to the entry of new legal actors, 'rights' and 'remedies' into the legal landscape concerning land and global governance. Drawing on the specific struggles of nomadic pastoralist herders in Mongolia the paper shines light on a larger pattern of 'real world' developments connected to the changing role of the state and the emergence and implications of new actors, norms and processes ${ }^{3}$ in global legal contexts.

The Oyu Tolgoi project is a $\$ 12$ billion investment to develop a copper and gold mine at Oyu Tolgoi in the Southern Gobi region (the 'OT Project'). In 2004, after completing mineral exploration work and fencing off land for mine construction eleven herding households from two districts were, following initial resistance and threats of forced

\footnotetext{
1 Conference and working paper delivered at the 6th Conference of the Postgraduate and Early Professionals/Academics Network of the Society of International Economic Law (PEPA/SIEL) 2017 in Tilburg, the Netherlands, 20-21 April 2017. Thank you to Phillip Paiement Assistant Professor at Tilburg University and Mislav Mataija from the European Commission, Legal Services for comments on this paper. 2 I am a Visiting Fellow at the Transnational Law Institute, King's College London, The Dickson Poon School of Law and an English qualified solicitor (LLB Law with French (Birmingham), M.Sc., PhD) experienced in the project financing and legal and regulatory reform of natural resource projects. I worked at White and Case LLP and Milbank Tweed, Hadley \& McCloy LLP. I served as legal advisor to the Ministry of Mineral Resources in Sierra Leone in a World Bank/DFID funded mining environmental, health and social regulatory drafting project and as civil society advisor to the Natural Resource Governance Institute on the Guinean Mining Code.

3 Inspiration for the methodology and title for this work come from P Zumbansen's 'actor, norm and process' framework. See P Zumbansen, 'Lochner Disembedded: The Anxieties of Law in a Global Context' (2013) 20 Indiana Journal of Global Legal Studies 29 and Zumbansen, Peer. "Defining the Space of Transnational Law: Legal Theory, Global Governance, and Legal Pluralism", (2012) 212 Transnational Law and Contemporary Problems 305-336.
} 
eviction from the local government, relocated to make may for the project. ${ }^{4}$ In 2012 and 2013, relocated herders organised into the Gobi Soil NGO and submitted two complaints concerning the project to an investor in the project: the International Finance Corporation (IFC), through its Complaints Advisory Ombudsman. The complaints detail how 89 herder households, reliant on traditional livestock systems like winter and summer camps ${ }^{5}$ were resettled using private informal land resettlement policies without adequate compensation. Herders self-identify as Indigenous people ${ }^{6}$ practising nomadic lifestyle and culture and with sacred relations with water sources like the Undai River and thus claim a right to claim land access. The Mongolian state as discussed in more detail later, does not acknowledge the herders' indigenous status, leading to a situation in which financial investors are becoming increasingly drawn into conversations surrounding the factual demarcation of indigenous status.

\section{Weak National Laws creating 'Policy' Space}

The government of Mongolia (GoM) has ratified an impressive number of international legal instruments. These include the International Convention on the Elimination of all Forms of Racial Discrimination, International Covenant on Civil and Political Rights with its protection of property rights and the International Covenant on Economic, Social and Cultural Rights pursuant to which the state guarantees to right to an adequate standard

4 See Oyu Tolgoi Complaint No. 1 dated 12 $12^{\text {th }}$ October 2012, <http://www.caoombudsman.org/cases/document-links/documents/OyuTolgoiCAOComplaint_Oct122012_Redacted.pdf.> accessed 18 November 2016.

${ }^{5}$ As stated in the 2012 complaint, for herders, winter camps have central significance given the length and severity of winter in Mongolia. Traditional livelihoods also rely on availability on pasture, reserve pastures and water wells which herders also lost access to: see Oyu Tolgoi Complaint No. 1 dated $12^{\text {th }}$ October 2012.

Traditional livelihoods also rely on availability on pasture, reserve pastures and water wells which herders also lost access to

6 The complaint states that 'we are Indigenous people who practice nomadic lifestyle and culture, and make livings from herding livestock that are heavily reliant on pastureland yields and capacity. We are legitimate owners of the pastureland with historical rights supported by traditional customs. However, the company does not accept it, yet it provided no justification to further their position. The company thinks we are not ethnic minorities so that we have no right to claim land access. Pasture rights are essential to support nomadic lifestyle and livelihoods infrastructure, but violations of pasture rights protection lead to collapse of traditional lifestyle based on pastoral nomadism', taken from Second Complaint of herder groups resettled in the Oyu Tolgoi Project dated February 11, 2013. 
of living and adequate food 7 . Mongolia is also one of very few states to have ratified the Optional Protocol to the International Covenant on Economic, Social and Cultural Rights (Optional Protocol) and consequently is subject to the UN Committee on Economic Social and Cultural Rights' recommendation processes. Article 10 of the 1992 Mongolian Constitution directly incorporates these treaties into domestic law ${ }^{8}$. However, as I will now argue, the meaningful implementation of these treaty obligations into the Mongolian context remains weak due to the consistent pressure of neoliberal market ideology. This domestic legal weakness and aggressive neoliberal market pressure has, I argue, made the practical involvement of financial investors and their policies a crucial part of Mongolian 'law making', 'rights' and 'enforcement' measures. A pertinent example of the concretisation of the 'weakness and pressure' narrative is seen in the fact that Mongolia has ratified the United Nations Declaration on the Rights of Indigenous Peoples (UNDRIP) but does not recognise pastoralist groups as 'Indigenous' within the 1992 Mongolian constitution. This as I later discuss, has resulted in an amazing domestic legal vacuum into which the EBRD and IFC are now drawn into matters like the factual demarcation of herder groups as 'indigenous' or 'vulnerable', with serious legal and social consequences for displaced herders.

Anthropological studies ${ }^{9}$ on the period of land collectivisation in 1940s Mongolia observe how the pastoral sector was organised around centralised collective farms relying on portable housing, seasonable movements to fulfil domestic and commercial needs ${ }^{10}$. Traditionally, local authorities accepted herders' traditional rights to land even though they were not formally registered with herders enjoying high social regard of

\footnotetext{
${ }^{7}$ Article 11 of the ICESCR protects the right to an adequate standard of living, as 'the right of everyone to an adequate standard of living for himself and his family, including adequate food, clothing and housing, and to the continuous improvement of living conditions'. In 2002 the CESCR made use of the convention's flexibility to establish a right to water within the series of socio-economic rights stating 'the right to water clearly falls within the category of guarantees essential for securing an adequate standard of living, particularly since it is one of the most fundamental conditions for survival': see the Committee on Economic, Social and Cultural Rights, General Comment 15, the right to water (Twenty-ninth session, 2003), U.N. Doc. E/C.12/2002/11 (2002) [3].

8 For example, article 10 states that Mongolia shall adhere to the universally recognized norms and principles of international law and pursue a peaceful foreign policy and it shall fulfil in good faith its obligations under international treaties to which it is a Party.

9 Sneath D, 'Land Use, the Environment and Development in Post-Socialist Mongolia' (2003) 31 Oxford Development Studies 441.

10 Ibid, these techniques included portable housing (the ger or yurt), seasonal movements and otor (foraging forays) which fulfilled both domestic subsistence livelihood needs such as meat, dairy, winter clothing and transportation and yield focused or commercial needs.
} 
their traditional animal husbandry work ${ }^{11}$. Following the collapse of state socialism in the 1990s and economic advice from the World Bank advancing the benefits of private land ownership by foreign entities, the GoM carried out political economy reforms embracing a broadly liberal and market orientated agenda. ${ }^{12}$ In Mongolia, these Lockean privatisation policies focused on unlocking the vast mineral reserves, with the OT Project constituting one of these transnational land policies in action. Such has been the success of privatisation policies in Mongolia that the World Bank estimates that $54 \%$ of Mongolian revenues derive from mining development projects. Related legal reform followed and in 1992, a new constitution permitted land, for the first time, to be held privately ${ }^{13}$ as well as a Land Law ${ }^{14}$ codifying the constitutional principle into land laws that prioritised registration and titling of private land.

What followed were asocial policy recommendations advocating privatisation designed to free the economy from inefficient state control, unlock agricultural value and promote tenure security. For example, issuance of certificates of possession to individuals and companies extending long-term exclusive access to land, thus making land open to investment. Given the importance of winter pastures to herders in the long and harsh Mongolian winters, the government issued certificates of possession on these lands permitting herders to use winter sites for sixty years with a provision for extension. Whilst they provide herders the right to negotiate with developers on compensation and resettlement, failure to reach agreement results in operations going ahead. ${ }^{15}$ The result is a strong legal framework for business and a correspondingly insecure one for customary rights holders.

In the OT Project, this weak domestic legal protection has given rise to the prevalence of new types of policy based 'rights' that are 'doing the work' of delinquent national law.

\footnotetext{
${ }^{11}$ Reference is made to interviews and conversations with resettled herders (translated from Mongolian to English and on file with the author).

12 Supra 8.

13 See for example article 5 stating that the land, except that in private ownership of the citizens of Mongolia, as well as the land subsoil, forests, water resources, and fauna shall be the property of the State. 14 Under article 30 of the 2002 Law of Mongolia on Land Law effective since 1994 and renewed in June 2002, Mongolian citizens, business entities and organizations may be granted the right to lease stateowned land for up to 60 years with the possibility of extensions for 40 years each.

15 Reference to informal conversations with researchers from the University of Queensland's institute on natural resources specifically working on Indigenous issues in Mongolia. Winters can last anywhere up to six months.
} 
The weakness of domestic law on land rights, indigenous peoples and resettlement in Mongolia means that private investors like the IFC and European Bank for Reconstruction and Development (EBRD) are finding greater policy spaces in which to shape and implement their own regulations and agenda on land and indigenous people that can speak to a diverse number of land connected groups in geographically plural jurisdictions. The result is the vocalisation of claims seen in the above cited complaints, in which herders conceptualise themselves as legal actors despite benefitting from formal legal protection as 'Indigenous'. Gaps in domestic legal protection means that informal land and indigenous policies, financial 'project finance' structures through which informal norms are implemented and non-judicial grievance mechanisms are rapidly becoming new 'legal' standards and methods of adjudication through which herders are claiming rights to land.

Perhaps, the obvious question to lawyers then, is perhaps, is this law? Should we be interested in transnational law even one that is understood as a methodological perspective on law in a global context rather than as a distinct legal field ${ }^{16}$ Should we be bothered with non 'legal' actors claiming 'rights' under informal norms and finance processes or are they simply irrelevant? There is after all, a clear tension (perhaps unnerving) between traditional state-centric ideas of law and approaches that appreciate the growing location of legal rights and remedies within, beyond and sitting in-between the boundary of the state and the market. This is of course, a personal choice dependent on one's own background and legal training and so it would be impossible to give an answer that would please all. Some scholars remain convinced of a purist state centred approach to law and others take a more cross border approach to law.

Use of these types of policies has been long known, advised on and assisted by practitioners' active in advising clients in cross-border transactions. ${ }^{17}$ Whilst these

\footnotetext{
16 Peer Zumbansen, Transnational Law, in: Encyclopaedia of Comparative Law (Jan Smits ed., 2nd ed., 2012), 898-935, at XX; for a similarly oriented analysis of transnational rules with a focus on sources rather than content, see already Emmanuel Gaillard, Transnational Law: A Legal System or a Method of Decision Making?,17:1 Arbitration International 59-71 (2001), 60-62.

17 Starting in the 1980s with the World Bank's in-house policy on involuntary resettlement and indigenous peoples, which were shaped into the Operational Directives of the 1990s and revised throughout the 1990s and early 2000s. The wider development community began to replicate the bank's
} 
types of policies do not constitute legally binding laws, the academy has called for analysis of these types of policies as important bodies of normative practice and international market standard setting guidelines. This is due to their fast proliferating within international, multilateral and bilateral institutions with the ensuing potential for application broadly across borders and within many geographically diverse projects with vastly differing legal systems and socio-historic contexts. If applied in projects these policies can directly (in the case of resettlement policies caused by project displacement or as sociologist Sassen calls 'Expulsions ${ }^{18}$ ) or indirectly (as in the case of policies on supply chain management and biodiversity) impact communities. Moreover, many of them come attached with their own non-judicial ombudsman grievance mechanisms through which communities can make direct complaints towards financial institutions on the socio-economic impacts of projects on communities ${ }^{19}$ and even draw attention to the adverse socio-economic effects of the finance structures through which the policies are implemented. For example, in one complaint against the Bujugali hydroelectric power plant, aggrieved local communities made direct reference in their complaint to the high margin on the loan agreements as an aggravating factor to the proper and careful consideration of resettlement issues. Surely, this type of global interconnectivity caused by increased financialization and globalisation combined with a lack of formal and robust legal protection on land and resettlement in many countries

resettlement policies with the OECD producing guidelines on resettlement planning in 1991, the European Bank for Reconstruction and Development producing its first environmental policy in 1991, indigenous policy in 2008, the Asian Development Bank formulating a resettlement policy in 1996 and indigenous policy in 1998, the Inter-American Development Bank adopted resettlement policy in 1998 and an indigenous policy in 2006 and the African Development Bank formulating a resettlement policy in 2002 (although it has refused to establish a stand-alone indigenous policy). Resettlement policies trickled into the private sector with the IFC as private arm of the World Bank producing its own involuntary resettlement policy in 2002 and indigenous policy in 2006. The following year, the Equator Principles were approved by 90 financial institutions across 37 countries covering over $70 \%$ of project finance debt worldwide, to form a corpus of globally valid norms for banks involved in project finance concerning regarding matters such as the rights of project affected people and indigenous people. See generally Cernea M, 'The 'Ripple Effect' in Social Policy and its Political Content: A Debate on Social Standards in Public and Private Development Projects', in Likosky M, Privatising Development: Transnational Law, Infrastructure and Human Rights (M. Nijhoff Publishers 2005) for a history on involuntary resettlement policies within international financial institutions. Safeguard policies cover a range of 'public interest' topics including environmental assessments, cultural diversity, biodiversity, supply chain issues, involuntary resettlement and Indigenous peoples

18 Saskia Sassen, Expulsions: Brutality and Complexity in the Global Economy (Harvard University Press 2014).

${ }^{19}$ These mechanisms were created to provide a degree of independent scrutiny and public accountability for compliance of its policies: for an overview of the inspection panel and its historical development see Alfredsson G and Ring R, The Inspection Panel of the World Bank : a different complaints procedure (Raoul Wallenberg Institute human rights library, Martinus Nijoff Publishers 2000). 
makes these types of policies of concern to public international lawyers.

Through the OT Project study, I suggest that globalised and financialised contexts of the law should also be of concern to the academy given their ability to practically effect subjects of international law: individuals and groups. After all, the notion of indigenous status claimed by herders follows the understanding in international law as applying to persons claiming a special socio-economic, cultural and communal relationship to traditional land: a position which legal case law and authority has given affirmative recognition. For herders, diversion of the river violated the human rights guaranteed by Mongolian and international legislation, specifically: water rights, pasture rights, livelihood rights and historical and cultural heritage protection rights. ${ }^{20}$ Herders claim, as traditional Indigenous legitimate owners, a fundamental ownership right to their traditional pastureland, collateral rights to livelihood, culture, pasture or food and water and even fundamental constitutional rights on land relating to prior consultation, participation in decision making and adequate financial compensation. They share the Indigenous commonality of having a special relationship to traditional land, but for diverse reasons discussed later such as no state recognition as indigenous, are denied formal recognition as indigenous under Mongolian law.

The contention is that mining operations have fractured their distinctive nomadic identity and access to grazing land and water vital to livelihoods. Herders thus wish to obtain meaningful compensation for the loss of traditional rights to land and to enjoy rights to free, prior and informed consent ${ }^{21}$ before further land activities occur. These are I am sure, rights that all indigenous and land rights scholars whether schooled in domestic, international or global legal perspectives can 'get behind'. What we find in the OT Project are simply new types of actors, norms and processes through which these rights are concretised, shaped and channelled. What the following does is draw attention to these new frontiers as part of a much larger pattern of 'real world' developments connected to the changing role of the state, the emergence and implications of new actors, norms and processes in global legal contexts of privatisation

\footnotetext{
20 Excerpts taken from Second Complaint of herder groups resettled in the Oyu Tolgoi Project dated February 112013.

21 The right of Indigenous people to FPIC in relation to developments on their land is a growing standard in international law with its clearest elaboration contained in articles 19 and 32(2) of the UNDRIP.
} 
and natural resource governance of relevance to this project and potentially many others involving financial investors.

Having shone light on the connection between weak domestic laws and the effect of unstable domestic protection on the ability of private investors to plug the gap with informal norms implemented through complex financial mechanisms like project finance and private grievance mechanisms in which affected communities can 'speak' directly to these informal norms and processes and how they have adversely affected their rights and livelihoods. Having thus made the case for the sincere consideration of informal norms, financial processes and non-legally recognised 'actors' in contemporary discussions on law making in a global context, the rest of the paper explores the 'real life' impacts of these 'extra-legal' actors, norms and processes on herder communities and the rule of law.

\section{The Role of the IFC and EBRD in the OT Project and the Entry of Project Finance 'Financialization' Processes}

Weak domestic laws and the increasing involvement of financial investors in demarcation of the land rights and identity of displaced herders also has implications in the types of 'networks' that herders are forced to negotiate, adjudicate and make their voices heard. In the presence of a strong legal system, we would expect this 'network' to consist of formal legal adjudication networks and due process procedures. What we find in the OT Project are communities making claims through 'financial' networks and nonlegal grievance processes. This inevitably draws into question the 'insulating' nature of project finance networks and how it might affect how private investors view issues like those relating to indigenous identity and economic trade off discussed later in this paper. The natural ideology in project financing networks is for all risk to be kept away from the project: pushed at 'arm's length'. The layered and risk averse nature of project finance has obvious implications for overall access to justice for communities that find legal and physical recourse to project sponsors or developers particularly challenging.

Through a limited liability special purpose vehicle, the OT Project is structured to 
insulate it from political, social, market and environmental risks, pushing them further away from the project. Indeed the 'success' of a project is not only vulnerable to disturbances in private markets but is highly sensitive to 'public outcries because it bears directly on social and environmental issues. ${ }^{22}$

Powerful shareholders and developers sit 'behind' the special purpose 'project company'. In this case, the OT project company is a 'shell' company owned by subsidiaries of Rio Tinto and the GoM. The 'layered' nature of project finance works to obfuscate legal relations such that affected communities remain unaware of the ultimate identity of the developers and how they might speak to the private entities that are ultimately responsible for restricting their ability to access land. One possible solution would be to make all developers disclose ownership structures and project party identities to host governments and local communities.

Pursuant to this layered structure, contracts for construction and operation are formed between the project company and third parties with strict limitation of liability provisions designed to 'shield' the project company from excessive liability and ultimately bankruptcy: ensuring limited recourse to the company. This is important as the project investors are paid entirely out of the project revenues. This makes the period up to project construction a high risk 'red light' period for investors. Ironically, it is also the period in which resettlement activities will occur leading to a severe conflict of interest for financial investors and the GoM, who of course have human rights obligations towards their citizens.

The financial viability of the financial structure is based on an approach to problem solving devoted to maintaining a certain level of liquidity within the project to ensure debt repayment. Consequently, a financially driven approach to problem solving if things go wrong is factored into the project through an obsessive pre-occupation with due diligence, timing and risk mitigation. Ensuring the timely construction of the project and its proper operation is crucial for lenders as it is fundamental to the success of the project and debt repayment. Specific sub-contracts relating to construction for example,

\footnotetext{
22 Shamir R, 'Corporate Social Responsibility: Towards a New Market-Embedded Morality?' (2008) 9 (2) Theoretical Inquiries in Law 371, 384.
} 
are made between the project company and a construction contractor. They are made subject to tight completion deadlines and limited liability provisions to protect the liquidity of the company. Construction contracts often contain liquidated damages provisions which work to compensate the project company in the event of construction default, delays and the resulting inability to repay project debt to financiers per repayment terms. These mechanisms work to incentivise the construction contractor to construct on time thus leaving little or no time to factor in engagement with communities who are claiming traditional connection to land. One possible solution would be to include an independently verified assessment within the Borrower's project construction completion certificate that affected land connected persons have been identified.

If resettlement activities were to be conducted the project company would sub-contract any resettlement implementation to a limited liability subsidiary to physically, legally and economically distance itself from those activities and their potential failures. Given this 'insulating' and 'distancing' ideology behind project finance, it is not difficult to see the temptation for project investors to get involved in identity issues and label herders 'vulnerable' as opposed to 'indigenous', as discussed later in this paper. This is especially the case where there is no domestic law clarifying the issue. Similarly, given the 'policy space' given to organisations under their mandates to cherry pick human rights and themselves determine which rights are to be respected and how, it is easy to see how complicated and time-consuming matters of land and indigenous peoples' rights will voluntarily enter into project design.

A 2015 report for the African Development Bank (AFDB) ${ }^{23}$ picks up on several issues within its own 2003 Involuntary Resettlement Policy. Each of these points demonstrate the ideological clash and difficulties that the AFDB and comparable institutions such as the IFC and EBRD have in incorporating these fundamentally conflicted social concerns into the economic ethos of their development operations, well typified in the complete failure of a 'social rate of return' indicators into project operations. ${ }^{24}$ The policy report

\footnotetext{
${ }^{23}$ Safeguards and Sustainability Series, Volume 1, Issue 3: Review of the implementation of the African Development Bank's 2003 Involuntary Resettlement Policy, 2015).

${ }^{24}$ Likosky M, Privatising Development : Transnational Law, Infrastructure and Human Rights (M. Nijhoff Publishers 2005) containing observations of chief bank social adviser Cernea on how many economists
} 
discussed the following specific barriers as compromising the implementation of land rights in development projects. Barriers include poor internal monitoring caused by a lack of incentives within the bank in monitoring the social aspects of the project with preference given to the monitoring of the project's physical progress and institutional fear over time delay and expense in preparing and submitting resettlement plans. An earlier legal ethnography study of the World Bank identifies how some departments have more 'power' than others 25 : bad news for those in the environmental and social teams and good news for those staffed in project operation and closure. The larger take away from this is acknowledgment that the entire financial network through which policies are implemented and communities are required to negotiate their claims is fundamentally designed to push socio-economic and cultural risks out of the project and safeguard timely project completion.

I argue that this financial ideology is key to understanding the institutional trends discussed in the rest of this paper that have been able to gain traction as 'rights' due to the weakness of Mongolian law.

Private investors like the IFC and EBRD have developed policies evidencing a legal right to land for Indigenous (PS 7) and resettled persons (PS 5). These apply where either physical or economic displacement are unavoidable because of a development project in which they are investing. The objective of the resettlement policy is to actively incorporate affected communities into projects, make positive contributions to development ${ }^{26}$ or, at a minimum, to do no harm to local communities. Land related rights for displaced non-Indigenous persons ${ }^{27}$ include compensation for loss of assets at

\footnotetext{
within the bank had tried to introduce the concept of a social rate of return into project governance but arguments against it were strong focusing on methodological and implementation difficulty.

25 Trubek D, Santos A, The New Law and Economic Development: A Critical Appraisal (CUP 2006).

${ }^{26}$ EBRD Performance Requirement 52014 on land and involuntary resettlement. Its objective is to mitigate adverse social and economic impacts from land acquisition and to restore, and where possible, potentially improve, their standards of living and/or livelihoods and IFC Performance Standards 2012 with a similar provision requiring that in addition to compensation for lost assets, if any, economically displaced persons whose livelihoods or income levels are adversely affected will also be provided opportunities to improve, or at least restore, their means of income-earning capacity, production levels and standards of living.

${ }^{27}$ IFC PS 5 states that displaced persons may be classified as persons (i) who have formal legal rights to the land or assets they occupy or use; (ii) who do not have formal legal rights to land or assets, but have a claim to land that is recognized or recognizable under national law; 19 or (iii) who have no recognizable legal right or claim to the land or assets they occupy or use.
} 
full replacement cost and other assistance to help them improve or at least restore their standards of living or livelihoods. ${ }^{28}$ Other land related rights for non-Indigenous displaced groups include community engagement, ${ }^{29}$ and the preparation of a resettlement action plan to mitigate against the adverse impacts of resettlement. ${ }^{30}$ For Indigenous persons, IFC PS 7 on Indigenous people, largely like that of the EBRD, expands consideration of Indigenous peoples' specific circumstances in developing mitigation measures for the acquisition of land subject to traditional ownership or under customary use. Other rights include the fair and equitable sharing of benefits associated with the use of resources central to the identity and livelihood of affected groups. ${ }^{31}$ Crucially, the policy emphasises the need for free, prior and informed consent $^{32}$ in international policy, also an idea gaining currency in legal circles. The policy builds on this type of open, informed and free dialogue by, for example, providing groups with the special right to be involved and consulted within project decision making.

In practice however, the default position under land resettlement policies is that neither displaced nor Indigenous groups have the right to refuse land acquisition or restrictions on land use that result in physical or economic displacement. The project's right of way is prioritised and resettlement in both traditional and non-traditional contexts is considered involuntary: a position evidenced by the name of both land policies as relating to 'involuntary resettlement'. Both the IFC and EBRD's operational policies explicitly refer to the protection of 'human rights' within project operations. ${ }^{33}$ Remarkably, the EBRD expressly connects the application of PS 5 with the universal respect for, and observance of, human rights and freedoms and specifically the right to adequate housing and the continuous improvement of living conditions contained in the UDHR and the ICESCR. ${ }^{34}$ Running parallel to the policy narratives on doing no harm and

\footnotetext{
${ }^{28}$ See IFC Performance Standard 5 on Land Acquisition and Involuntary Resettlement, para 9.

29 Ibid, para 10.

30 Ibid para 12 .

31 Ibid.

32 Interestingly the comparable World Bank standards to Indigenous persons: Operational Policy 4.12, uses the less stringent version of 'free, prior and informed consultation' leading to broad community support' demonstrating a fragmentation and inconsistency within the policies and international lawmaking.

33 In Performance Standard 1 of the IFC policy, para 4 states that several cross cutting topics such as climate change, gender, human rights and water are addressed across multiple performance standards.

34 EBRD PR 5 para 3.
} 
positive development outcomes runs the established policy that the political prohibitions within their articles of association mean that development finance institutions like the World Bank and the IFC have not agreed to directly incorporate human rights into the policies. ${ }^{35}$

Contradictions abound and it is perhaps the institutional temperament of the financial investor rather than any policy guideline that is the most decisive consideration in the practical implementation of policy. Informal discussants ${ }^{36}$ noted how management remains aware of this ambiguity between promoting policies speaking to the full spectrum of human rights: civil, political, collective, cultural and green rights, and the practical reality that only civil and political rights directly relevant to the development of market economies will be actively promoted. Discussions with bank staff reveal how application of policies are 'scoped' around institutional mandates. For example, decisions over policy operationalisation are typically based on an economic method of implementation called the new public management which sees the export of rational market thinking and measurable ('tick the box') performance indicators for public policy issues ${ }^{37}$. As one interviewee stated: decisions to enter discussions over whether to make positive development contributions or simply do no harm will have a direct correlation with the amount the institution is investing in the project and its amount in relation to other lenders as a means of leveraging influence.

This socio-economic trade-off is present within IFC Standards stating that the level of IFC's engagement is determined by the nature and scope of the proposed investment or advisory activity, as well as the specific circumstances of the collaboration and relationship with the client. ${ }^{38}$ This sentiment was echoed within discussions in which commitment to public policy issues were said to be dependent on project economics ${ }^{39}$

\footnotetext{
35 Reference is made to World Bank webinar in which the author participated on 'The Evolution of Safeguards: The Proposed Environmental and Social Framework'. World Bank participants comprised of Stefan Koeberle (Director of Operations Risk Management), Agi Kiss (Regional Safeguards Advisor for Europe and Central Asia), Una Meades (World Bank Senior Legal Counsel) and Glenn Morgan (Safeguards Advisor): on file with the author.

${ }^{36}$ Reference is made to informal conversations with senior members of an IO's environmental and social safeguards team that remain confidential and on file with the author.

37 Hood C, "The "New Public Management" in the 1980s: Variations on a Theme' (1995) 20 Accounting, Organizations and Society 93, 97.

38 See paragraph 19 of the 2012 IFC Environmental and Social Performance Standards.

39 Supra 35.
} 
and even the type of development project undertaken, with the understanding that road projects are more development friendly as communities can use roads with mines being 'dirtier' and thus requiring a higher level of social engagement.

The following section will discuss the growing trend of financial investors to factually demarcate in 'who' is indigenous in the light of poor legal protection for land connected groups in Mongolia. Performance Standard 7 makes Indigenous determination a matter for the IFC or EBRD's private client who may seek input from competent professionals 40. The World Bank, IFC and EBRD recognise that there is no universally accepted definition of Indigenous peoples ${ }^{41}$ and take this legal ambiguity to present their own definitions. In determining Indigenous status, the World Bank follows the lead of international law when applying its policy on Indigenous people $\mathrm{e}^{42}$. However, clarifying the legal position is, as investors note ${ }^{43}$, a complex process given the sheer number of definitions of Indigenous under international law and the differences within these definitional approaches leaves the scope for deciding which groups are Indigenous fragmented, inconsistent and arguably, open to manipulation.

Common to the $\mathrm{IFC}^{44}$ and $\mathrm{EBRD}^{45}$ is the use of the term in a generic sense to refer to a distinct social and cultural group possessing the following characteristics in varying degrees including self-identification, collective attachment to geographically distinct habitats and distinct language. The EBRD also classifies as Indigenous, people with descent from populations who have traditionally pursued non-wage (and often nomadic/transhumant ${ }^{46}$ ) subsistence strategies and whose status was regulated by their own customs or traditions.

Studies on Indigenous rights in the context of World Bank policy conclude that in states where Indigenous groups are politically organised and familiar with World Bank policy,

\footnotetext{
40 IFC Performance Standard 7, para 8 stating that the client will identify, through an environmental and social risks and impacts assessment process, all communities of Indigenous Peoples within the project area of influence who may be affected by the project, as well as the nature and degree of the expected direct and indirect economic, social, cultural.

41 Supra, 34.

42 Supra 34.

43 Supra 35.

${ }^{44}$ IFC Performance Standard 7, para 5.

45 EBRD Performance Requirements 7, para 3.

46 Ibid para 4.
} 
international organisations are almost inevitably drawn into processes of social group self-identification and definition.47 In another study of World Bank practices in Morocco, Sarfaty finds that bank managers decided not to recognise Berbers as indigenous notwithstanding self-identification. The reason for this was an alignment of policy practice with the state's non-recognition of ethnic minorities within their borders as Indigenous. ${ }^{48}$ Similarly, in other development projects, international organisations have justified the non-application of indigenous policy based on lack of national recognition notwithstanding factual claims made by local communities in Africa and India claiming Indigenous status. ${ }^{49}$

The OT Project provides a further case in point. Performance standards 5 on involuntary resettlement were triggered by both the IFC and EBRD. Notwithstanding the EBRD's express policy position classifying as Indigenous, people with descent from populations who have traditionally pursued non-wage (and often nomadic/transhumant) subsistence strategies, the internal decision was made not to apply the performance requirement 7 on IPs. This conflict meant that financial institutions were, through grievance complaints lodged by herder households ${ }^{50}$, brought directly into discussions on the herders' claim of indigenous status and special connection to land, which investors, with state backing, continue to resist. Drawing on informal conversation with senior interlocutors, it emerges that the practice of applying the Indigenous definition remains uncertain. Both PS 7 policies contain the provision that IPs do not lose their status because of dispossession or might live in mixed or urban communities visiting their land on a seasonal basis. Yet, interlocutors expressed the view that the use of mobile phones by Indigenous people erodes Indigenous status.

What we might deduce from these examples is a developing bank of precedents in

\footnotetext{
${ }^{47}$ See I Brownlie GS Goodwin-Gill \& S Talmon, The Reality of International Law: Essays in Honour of Ian Brownlie (Clarendon 1999) 328; B Kingsbury, 'Indigenous Peoples' in International Law: A Constructivist Approach to the Asian Controversy' (1998) 92 AJIL 414.

${ }^{48}$ Sarfaty GA, 'The World Bank and the Internalization of Indigenous Rights Norms' (2005) 114 The Yale Law Journal 1791.

49 See the Bujugali hydroelectric project in Uganda, the Second Water Supply and Environmental Sanitation Project in Karnataka approved in 2001 affecting the Lambanis and Siddis, ethnic groups with distinctive cultural practices who could arguably qualify as Indigenous peoples under Bank policy and on Asia, see more broadly Kingsbury B, 'Indigenous Peoples' in International Law: A Constructivist Approach to the Asian Controversy' (1998) 92 AJIL 414.

50 CAO Assessment Report, Second Complaint (Oyu Tolgoi-02) Regarding the Oyu Tolgoi Project (IFC \#29007 and MIGA \#7041).
} 
which private investors have created a policy space in which to make decisions on factual identity demarcation. In many cases land connected communities are already subject to legal recognition blocks at the state level. Financialization and globalisation processes through which now private investors also have a say in identity have the potential to further compound access to justice for land connected groups. The EBRD's potential future investments within Middle Eastern countries such as Jordan ${ }^{51}$ which have, like Morocco, communities self-identifying as nomadic and into which future investments are planned, will potentially provide further examples of investor determination. This pattern of what we might call 'investor-state sovereighty' over factual indigenous demarcation constitutes major transnational dilemmas for indigenous struggles directly born out of growing financialization and globalisation.

Research has also discovered a recent trend amongst institutions, confirmed in interviews away from using the term Indigenous in favour of 'vulnerable ${ }^{52}$ ' persons to whom special measures such as compensation apply. The EBRD reserves ${ }^{53}$ the term vulnerable groups to those who, by gender, ethnicity, age, physical or mental disability, economic disadvantage, or social status are more adversely affected by displacement than others. ${ }^{54}$ The institutional choice to use the alternate 'vulnerable' label over that of 'Indigenous' is typically justified through political processes designed to protect national sovereignty and avoid further legal fragmentation within international legal definitions discussed above. ${ }^{55}$

Categorising groups as 'vulnerable' might work to capture the economic disadvantage or social status experienced by groups in this case. However, this classification also carries significant adverse legal ramifications for herders. Arguably, the replacement of vulnerable for Indigenous erases the heart of Indigenous identity: the struggle for recognition of their special attachment to traditional land and related to this, the unique

51 See the list of new wind, waste, solar and power projects project finance by the EBRD in Jordan: available at: http://www.ebrd.com/work-with-us/project-finance/project-summarydocuments.html?1=1\&filterCountry=Jordan.

52 Interview with Senior Land Policy Lead at a development organisation and to supra 35.

53 Performance standard 5, para 12.

54 Ibid, in the context of displacement vulnerable people, include those living below the poverty line, the landless, the elderly, women- and children-headed households, ethnic minorities, natural resource dependent communities or other displaced persons who may not be protected through national land compensation or land titling legislation.

55 Supra 35. 
type of discrimination and marginalisation they have experienced in ongoing processes of land dispossession. Consequently, the removal of the Indigenous label in favour of a homogenous vulnerability label erodes the specificity of their struggle and erases the building blocks upon which indigenous groups can claim legal recognition and elevated rights of compensation and consultation such as the emerging right of free, prior and informed consent. The above evidence of institutional dis-engagement with Indigenous policy has the effect of continuing the dispossession of land connected persons through policy praxis into an international space. Ultimately, the 'politics' of sovereignty is deployed as a shield through which to protect the integrity of its economic mandate and dis-engage with social settings that might have adverse impacts on project functionality and economics.

\section{Conclusion}

This paper has drawn attention to the role of new actors, norms and processes in global governance. Specifically, it shines light on the case of the Oyu Tolgoi project and the role played by weak domestic laws on land and indigenous rights as crucial for understanding the entry of new 'legal' actors, 'rights' and 'remedies' into the legal landscape on land and global governance. Drawing on the specific struggles of nomadic pastoralist herders in Mongolia the paper shines light on the relevance of project finance structures, informal land policies and factual determination of 'indigenous' identity shaped by financial institutions involved in the financing of the project. Through this case study it hopes to draw attention to a larger pattern of 'real world' developments connected to the changing role of the state, the emergence of new actors, norms and processes in modern processes of globalisation and financialization and the effect of the same on the rights of affected communities. 